\title{
Protein Biomarkers for the Diagnosis of Alzheimer's Disease at Different Stages of Neurodegeneration
}

\author{
Mar Pérez ${ }^{1}$, Félix Hernández ${ }^{2,3}$ and Jesús Avila ${ }^{2,3, *(D)}$ \\ 1 Departamento de Anatomía Histología y Neurociencia, Facultad de Medicina UAM, 28029 Madrid, Spain; \\ mar.perez@uam.es \\ 2 Centro de Biología Molecular Severo Ochoa (CSIC-UAM), 28049 Madrid, Spain; fhernandez@cbm.csic.es \\ 3 Network Center for Biomedical Research in Neurodegenerative Diseases (CIBERNED), 28031 Madrid, Spain \\ * Correspondence: javila@cbm.csic.es; Tel.: +34-911964564
}

Received: 14 July 2020; Accepted: 11 September 2020; Published: 15 September 2020

\begin{abstract}
Mainly obtained from familial Alzheimer's disease patients' data, we know that some features of the neurodegenerative start several years before the appearance of clinical symptoms. In this brief review, we comment on some molecular and cellular markers appearing at different stages of the disease, before or once the clinical symptoms are evident. These markers are present in biological fluids or could be identified by image techniques. The combined use of molecular and cellular markers will be of interest to determine the development of the different phases of the disease.
\end{abstract}

Keywords: tau; amyloid; PET; CSF

\section{Introduction}

Tissue degeneration occurs during aging. Early markers to detect this process are needed to prevent such degeneration. In this regard, Alzheimer's disease (AD), one of the most prevalent neurodegenerative conditions, is characterized by two main aberrant structures, namely senile plaques (extracellular deposits composed of beta-amyloid (A $\beta$ ) peptide oligomers) and neurofibrillary tangles (intraneuronal aggregates composed of tau protein).

There are two types of AD, one with a familial origin (FAD) and the other sporadic (SAD). In the former, plaques appear up to 20 years before clinical symptoms of the disease, whereas tangles occur around 5 years before [1]. The development of these clinical features takes place at different ages in FAD (early-onset) and SAD (late-onset). Developing before 60 years of age, FAD is caused by the presence of mutations at specific sites in three genes: APP, PSEN1 and PSEN2. These mutations are very early markers of the disease [2]. In contrast, the onset of SAD occurs later, after 65 years of age. Some genetic variants (not mutations) have been described in this form of AD. These genetic variants are risk factors for early onset of the disease. In this regard, variant 4 of ApoE accelerates the onset of the condition [3]. Additionally, aging is a major risk for the development of AD [4]. Moreover, several risk factors (see Table 1) related to lifestyle can also accelerate the development of dementia [5]. Life style factors, unlike aging or genetic factors, are modifiable factors and their modification could retard the development of the disease [5]. 
Table 1. List of risk factors to accelerate aging and neurodegenerative disorders like Alzheimer's disease (AD). Several of these factors have been indicated [6,7] and some of them, like diabetes, obesity or hypertension, are risk factors for cardiovascular diseases [8]. On the other hand, chronic stress could be a main and earlier risk factor to accelerate aging [9].

\begin{tabular}{c}
\hline Risk Factors to Accelerate Aging \\
\hline Chronic infections \\
\hline Physical inactivity \\
\hline Dysbiosis \\
\hline Diet \\
\hline Chronic stress \\
\hline Disturbed sleep \\
\hline Diabetes \\
\hline Obesity \\
\hline Hypertension \\
\hline Hypercholesterolemia
\end{tabular}

\section{Results}

\subsection{AD Diagnosis}

Autopsy criteria based on the presence of plaques and tangles in the brain for the proper and final diagnosis of AD were defined many years ago [10]. However, earlier diagnoses, based on early biomarkers, are required to prevent, or retard, the development of the disease. In this regard, the concentrations of components of plaques (amyloid) and tangles (tau) in fluids like cerebrospinal fluid (CSF) have been used as biomarkers of the disease [11], and image analysis, like positron emission tomography (PET), has been used to detect the presence of amyloid or tau aggregates [12].

\subsection{CSF}

CSF allows for the removal of waste products from the brain, among these the residues resulting from dead or damaged cells [13]. Measurement of changes in the concentration of $\mathrm{A} \beta$, tau or phosphorylated tau in CSF is now standard practice for the diagnosis of AD. Some patients show increased levels of tau and phosphorylated tau in CSF, due to its release from damaged or dying neurons, but reduced levels of amyloid, possibly because of the conversion of soluble amyloid into aggregates of the peptide, which do not circulate in CSF [14,15]. However, at different phases of the disease, different levels of total tau or different levels of phosphorylated tau, modified at specific residues present at specific regions of its molecule, could be found in the CSF of the patients. Since distinct regions of tau can be phosphorylated [16], we will comment on that.

\subsection{Tau Protein Phosphorylation}

Tau, from the central nervous system, can be modified by phosphorylation at different residues along its molecule tau is a phosphorylated protein, containing 85 potential serine (S), threonine (T) and tyrosine $(\mathrm{Y})$ phosphorylation sites. Phosphorylation regulates many processes such as the binding to microtubules [17], its subcellular distribution and axonal transport [18,19]. The binding of tau to microtubules is regulated by its phosphorylation at specific sites of its molecule [16]. Tau phosphorylation, at different residues, correlates with the presence of different pathologies (tauopathies), including Alzheimer's disease [20,21]. Aberrant phosphorylation causes the disassembly of microtubules and changes in the organization of the neuronal cytoskeleton. In addition, phosphorylated tau can accumulate at the neuron cytoplasm to induce the formation of tau oligomers and aggregates like fibrillar filaments and tangles [22]. Tau is a substrate for protein kinases, especially proline-directed 
kinases such as GSK3 $\beta$ [23] but cyclin dependent kinases and mitogen activated protein kinases also phosphorylate Tau $[24,25]$. GSK3 $\beta$ and cdk5 may play a relatively more prominent role in tau phosphorylation in the human brain [23].

Phosphorylation of different tau sites (Tyr18, Ser199, Ser202/Thr205, Thr231, Ser262, Ser396 and Ser422) could be used to measure the progression of Alzheimer's disease [26], at the determinate by looking at postmortem issues. We will comment below about it.

Hyperphosphorylation of tau may result from an imbalance in the activity of tau protein kinases and tau phosphatases. Several studies have revealed the role of phosphatase PP2A on tau dephosphorylation $[27,28]$. Regulation of the phosphorylation state and microtubule-binding activity of Tau by protein phosphatase 2A [28]. Furthermore, PP2A inhibition produces in vivo deregulation of many brain Ser/Thr kinases implicated in AD, including GSK3 $\beta$ [29] and cdk5 [30]. These kinases are also known as tau kinase 1 and tau kinase 2, respectively, for example [17]. Thus, PP2A dysfunction can induce several events that contribute to neuronal and synaptic damage in AD. Several therapeutic strategies are based on the activation of this phosphatase [31].

Recently, a soluble phosphorylated tau signature that links tau, amyloid and the stages of FAD has been reported [32]. The presence of P-tau 217 and P-tau 181 correlates with the development of amyloid plaques at earlier stages of the disease, before neuronal atrophy and changes in brain metabolism occur. P-tau 217 over P-tau 181 have been proposed as early markers of the disease in plasma samples [33]. Furthermore, neuronal atrophy is accompanied by P-tau 205/P-tau 202. Later on, tau tangles develop and total tau increases in the brains of AD patients [32]. Several protein kinases can modify the phosphorylated tau residues. In this context, P-tau 217 and P-tau 181 are modified by protein kinase cdk5, which is activated by $A \beta[34,35]$. This activation can occur during very early (asymptomatic) stages of the disease. Afterwards, tau phosphorylation at site 205 (probably modified by GSK3) and at site 202 (modified by GSK3) [16] can occur, correlating with a decrease in gray matter (loss of dendritic arborization and synaptic transmission), yielding the stage of neuronal dysfunction observed in the AD brain [32]. Finally, the development of tau tangles, related to an increase in total tau in CSF, announces the appearance of clinical symptoms and the onset of $A D$. In addition to $A \beta$ and tau, other markers such as neurofilament light chain NF-L and CX3CL1 (fractalkine) are found in the CSF of AD patients. The presence of NF-L, or other neurofilament proteins, in blood correlates with the axon damage that occurs during neurodegeneration. This damage causes the release of neurofilament proteins into CSF and these proteins are then circulated into the blood. Thus, quantitative analyses for detecting NF-L (or phospho neurofilament heavy chain (NF-H)) in CSF (or blood) have been developed for the diagnosis of neurodegenerative diseases [36]. On the other hand, damaged neurons may secrete lower amounts of CX3CL1 than healthy neurons. It may result in a change (activation) of microglia cells. In this regard, lower levels of CX3CL1 have been reported in the CSF of AD patients compared to that of non-demented subjects [37]. It is known that microglia could be activated by amyloid beta and it enhances inflammation [38], and facilitates the development of tau pathology [39]. Although, there are other possible AD markers related to microglia cells, little is known about their presence in CSF [40].

Furthermore, the presence of nucleic acids in CSF (or blood) as putative AD biomarkers has been put forward. A low concentration of mitochondrial DNA in CSF has emerged as a preclinical marker of AD [41]. Interestingly, this marker is not present in other tauopathies like Creutzfeldt-Jakob disease [42]. In addition, in blood cells, the methylation of specific genes can be found mainly in $\mathrm{AD}$ patients, thereby pointing to the utility of these epigenetic markers to detect preclinical stages of $\mathrm{AD}$ [43]. Additionally, some microRNAs in plasma samples from AD patients are increased compared to controls [44]. However, to date, the concentrations of tau and $A \beta$ in plasma have been the most widely studied potential markers of $\mathrm{AD}$. For $\mathrm{A} \beta$, the characterization and levels of autoantibodies present in AD patients have been studied [45]. Regarding tau, an increased level of P-tau 181 has been observed in the plasma of AD patients [46], but not in other tauopathies [33]. In most recent publications, the presence of p-tau 217 in plasma from people at very early preclinical stages has been reported [47,48]. In general, the use of plasma rather than CSF analysis is increasing since the former 
involves non-invasive extraction of samples. Furthermore, the isolation of tears for the detection of possible AD biomarkers may provide an even less invasive approach. In this regard, a recent study has corroborated the presence of specific miRNAs in the tears of AD patients [49]. This finding is, therefore, a good starting for the search of potential AD markers in this fluid.

\subsection{Positron Emission Tomography}

Another diagnostic approach in $\mathrm{AD}$ is the analysis of the presence of $\mathrm{A} \beta$ or tau protein aggregates by positron emission tomography (PET). In this technique, radiopharmaceutical tracers, linked to a radioisotope, bind to the $A \beta$ or tau aggregates. The presence of aggregates is detected by measuring radioisotope decay. Two radioisotopes, namely $\mathrm{C}^{11}$ or $\mathrm{F}^{18}$, are commonly used. $\mathrm{C}^{11}$ has a half-life of $20 \mathrm{~min}$, whereas $\mathrm{F}^{18}$ has a half-life of $110 \mathrm{~min}$, making the latter more suitable. Additionally, compounds related to thioflavin (ThT), which binds to $\beta$-sheet regions, have been used to bind to $A \beta$ and tau aggregates. Tracers were first designed for the former, the Pittsburg B compound called PIB-C11 being a pioneer of these compounds. PET is a non-invasive tool for amyloid imaging in humans [50]. In addition, PIB- $C^{11}$ shows stronger binding to $\mathrm{A} \beta$ oligomers than ThT [51]. Moreover, when using PET, PIB- $\mathrm{C}^{11}$ can be complemented by FDG- $\mathrm{F}^{18}$, a tracer of glucose metabolism, since an inverse relation between these signals has been reported in the brains of $\mathrm{AD}$ patients [52].

PIB- $\mathrm{C}^{11}$ and other compounds like flutemetanol $\mathrm{F}^{18}$, florbetapir $\mathrm{F}^{18}$ and florbetaben $\mathrm{F}^{18}$ react mainly with $A \beta$ aggregates, whereas the tracers AZF469 or FDDNP can bind to both $A \beta$ and tau [53,54].

It is known that looking at clinical symptoms, the disease could be divided in different stages, but to measure underlying pathology that is present previously to the appearance of clinical features, the use of amyloid PET could be a suitable tool [55]. Additionally, this tool could be used for differential diagnosis of neurodegenerative and neuroinflammatory disorders [56]. On the other hand, visual evaluation of images is the standard way used by A $\beta$ PET examination data. Since that way could result in a subjective analysis, an objective quantitative evaluation for image interpretation has been suggested [57]. However, no main changes were obtained by the comparison of the PET-only amyloid quantification method and a visual evaluation, using the 14C-Pittsburg compound (PiB) for PET analysis. The use of other radioactive tracers mainly F18 tracers, like florbetapir, flutemetanol or florbetaben, have allowed one to find a good correlation between, for example, florbetapir images and cortical amyloid pathology or to differentiate areas with frequent plaques from those containing sparse plaques [58]. Additionally, PET analysis can be used to look for asymmetries of A $\beta$-fibrillary plaques burden, an asymmetry, that could be associated with microglia activation in AD or in mouse models, for the disease [59].

Several tracers have been described for PET imaging of tau. The first generation of tracers included FAV-1451- $\mathrm{F}^{18}$ THK-5317- $\mathrm{F}^{18}$, T807 and PBB33 and the second-generation MK-624-F ${ }^{18}$, RO-948 and JNJ $311-\mathrm{F}^{18}$. Both first- and second-generation tau tracers are based on the detection of specific binding to the $\beta$-sheet regions of aggregated tau [52]. Various tau filament folds have been described for aggregates present in tauopathies like AD and cortical basal degeneration (CBD) [31]. These distinct folds indicate different $\beta$-sheet regions that react in a particular manner to the tracers.

A possible advantage of PET imaging for tau over amyloid for AD diagnosis is that the former predicts not only the amount but also the localization of the atrophy. This observation thus indicates that PET imaging for tau outperforms that for amyloid in the context of monitoring AD development [60].

\subsection{How the Data of CSF and PET Could Complement Each Other to Indicate the Progress of the Disease}

Based on the amyloid cascade hypothesis [61], amyloid pathology could facilitate tau pathology, for example by increasing tau phosphorylation. In this way, extracellular amyloid could bind to a cellular receptor, upon binding to the receptor, a signaling pathway could be activated and, as a consequence of that, different tau kinases could activate to modify specific sites at the tau molecule. Different amyloid receptors could bind to different receptors. At the very early stage, phosphotau 181 and 217 could be found in CSF [47]. At that stage, the level of amyloid is increased, and it can be 
already identified by PET analysis [32]. Amyloid, at that level, should bind to higher affinity receptors. An example could be the binding of amyloid to the alpha 7 nicotinic receptor [62]. Upon the binding cdk5 could be activated promoting the phosphorylation at tau residues 181 and 217. This modification may take place in some specific neurons that could be damaged and secrete phosphorylated tau to CSF. In addition, cdk5 (also known as tau kinase 2) facilitates amyloid processing of APP and cdk5 activator, p25 enhances cdk5 but reduced GSK3 (also known as tau kinase 1) activity [63].

At the later stages, the amyloid level increases and it could bind to other cell receptors, involving alternative signaling pathways and activation of other kinase like GSK3. For example, amyloid could bind to an insulin receptor [64,65], increasing GSK3 activity and in the phosphorylation of tau residues 202 and 205. Other suitable receptor could be the $\alpha_{2 \mathrm{~A}}$ receptor, amyloid beta oligomers bind $\alpha_{2 \mathrm{~A}}$ adrenergic receptors, this triggers GSK3 activation and it results in tau phosphorylation at residue 202 [66] (see Figure 1). Phosphorylation at different sites may occur in different neurons at different times. Neurons containing phosphorylated tau at specific residues could secrete that protein to the extracellular space and it could be found in CSF. Different phosphorylations can occur at different stages of the disease and could indicate different stages of neurodegeneration. Finally, the presence of tau tangles, which can be analyzed by PET studies, correlates with an increase in the amount of total tau in CSF [32]. Thus, CSF and PET analysis could complement each other to indicate the stage of Alzheimer's disease.

A

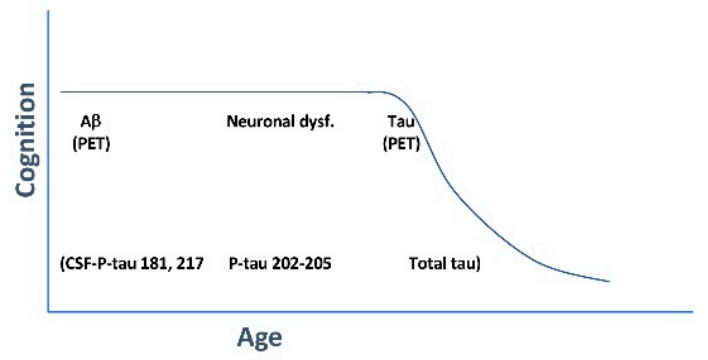

B

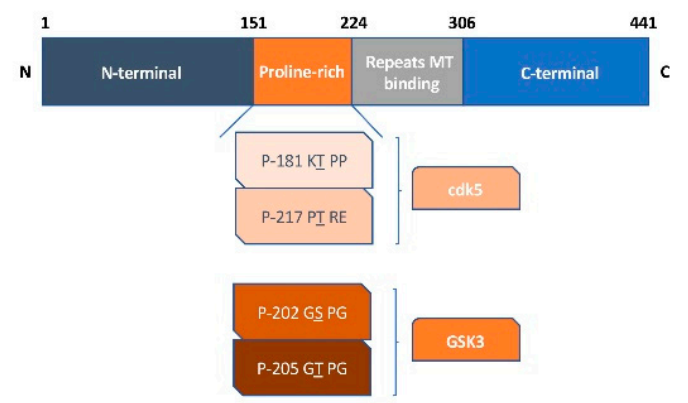

Figure 1. Phosphotau as the AD marker. (A) The diagram shows several markers for AD progression. Phosphorylation at several tau epitopes can be used as a marker for AD. At the very early stage, phosphotau 181 and 217 could be found in cerebrospinal fluid (CSF). At that stage, the level of amyloid is increased, and it can be already identified by PET analysis. At later stages, amyloid level increases and it could bind to other cell receptors, involving alternative signaling pathways and activation of other kinase like GSK3. (B) Schematic diagram of the Tau protein showing phosphorylation at residues, modified by GSK3 and cdk5, at the proline rich region of the molecule.

\section{Conclusions}

In summary, in this short review, we briefly commented on the nature of some biomarkers obtained from fluid samples, mainly CSF and plasma of AD patients, and on AD diagnosis using imaging techniques, which are based on the detection of the two major hallmarks of $\mathrm{AD}$, namely amyloid (senile plaques) and tau (neurofibrillary tangles) aggregates. 
In addition to the use of the aforementioned biomarkers, additional tests should be conducted to obtain a complete picture of the status of a potential AD patient. These analyses may involve neurological observation, neuropsychological tests or the use of electroencephalography (EEG) or event-related potential (ERP) indices [67] as biomarkers of AD [68]. In this regard and the context of cognitive function, the contribution of gamma oscillations also emerges as a relevant feature to examine in potential patients [69]. Additionally, other biomarkers of cognitive deficiency, like the failure of the default mode network (DMN), have been proposed as earlier biomarkers of AD [70]. In this regard, magnetic resonance analyses are also important. Thus, the use of magnetoencephalography as a potential non-invasive technique to study brain function and to determine progression to dementia could be a relevant tool in the future [71]. Thus, these many factors (and markers) can serve to indicate the development of AD. In some cases, additional information may be required to determine how the disease will develop in a potential Alzheimer's patient, as suggested in the Alzheimer Precision Medicine Initiative [72].

Although this review does not address tau-targeting therapies for $\mathrm{AD}$, good references can be found in $[73,74]$.

Author Contributions: All authors have read and agreed to the published version of the manuscript. M.P., F.H. and J.A. have participated in the preparation and writing of the manuscript.

Funding: This research has been founded by grants of Plan Estatal, Spain and CIBERNED.

Acknowledgments: We acknowledge the valuable work of Nuria de la Torre in editing this manuscript.

Conflicts of Interest: The authors declare no conflict of interest.

\section{Abbreviations}

$\begin{array}{ll}\text { A } \beta & \text { Beta-amyloid } \\ \text { AD } & \text { Alzheimer's disease } \\ \text { ApoE } & \text { Apolipoprotein E } \\ \text { APP } & \text { Amyloid beta precursor protein } \\ \text { CBD } & \text { Cortical basal degeneration } \\ \text { CSF } & \text { Cerebrospinal fluid } \\ \text { DMN } & \text { Default mode network } \\ \text { EEG } & \text { Electroencephalography } \\ \text { ERP } & \text { Event-related potential } \\ \text { FAD } & \text { Familial Alzheimer's disease } \\ \text { GSK3 } & \text { Glycogen synthase kinase 3 } \\ \text { NF-H } & \text { Neurofilament heavy chain } \\ \text { PET } & \text { Positron emission tomography } \\ \text { PIB-C } & \text { Pittsburg B compound } \\ \text { PSEN1 } & \text { Presenilin 1 gene } \\ \text { PSEN2 } & \text { Presenilin 2 gene } \\ \text { SAD } & \text { Sporadic Alzheimer's disease } \\ \text { ThT } & \text { Thioflavin }\end{array}$

\section{References}

1. Bateman, R.J.; Xiong, C.; Benzinger, T.L.S.; Fagan, A.M.; Goate, A.; Fox, N.C.; Marcus, D.S.; Cairns, N.J.; Xie, X.; Blazey, T.M.; et al. Clinical and biomarker changes in dominantly inherited Alzheimer's disease. N. Engl. J. Med. 2012, 367, 795-804. [CrossRef] [PubMed]

2. Price, D.L.; Tanzi, R.E.; Borchelt, D.R.; Sisodia, S.S. Alzheimer's disease: Genetic studies and transgenic models. Annu. Rev. Genet. 1998, 32, 461-493. [CrossRef] [PubMed]

3. Strittmatter, W.J.; Saunders, A.M.; Schmechel, D.; Pericak-Vance, M.; Enghild, J.; Salvesen, G.S.; Roses, A.D. Apolipoprotein E: High-avidity binding to beta-amyloid and increased frequency of type 4 allele in late-onset familial Alzheimer disease. Proc. Natl. Acad. Sci. USA 1993, 90, 1977-1981. [CrossRef] [PubMed] 
4. Hou, Y.; Dan, X.; Babbar, M.; Wei, Y.; Hasselbalch, S.G.; Croteau, D.L.; Bohr, V.A. Ageing as a risk factor for neurodegenerative disease. Nat. Rev. Neurol. 2019, 15, 565-581. [CrossRef] [PubMed]

5. Barnes, D.E.; Yaffe, K. The projected effect of risk factor reduction on Alzheimer's disease prevalence. Lancet. Neurol. 2011, 10, 819-828. [CrossRef]

6. Chen, S.T.; Siddarth, P.; Ercoli, L.M.; Merrill, D.A.; Torres-Gil, F.; Small, G.W. Modifiable risk factors for Alzheimer disease and subjective memory impairment across age groups. PLoS ONE 2014, 9, e98630. [CrossRef]

7. Østergaard, S.D.; Mukherjee, S.; Sharp, S.J.; Proitsi, P.; Lotta, L.A.; Day, F.; Perry, J.R.B.; Boehme, K.L.; Walter, S.; Kauwe, J.S.; et al. Associations between Potentially Modifiable Risk Factors and Alzheimer Disease: A Mendelian Randomization Study. PLoS Med. 2015, 12, e1001841, discussion e1001841. [CrossRef]

8. Baumgart, M.; Snyder, H.M.; Carrillo, M.C.; Fazio, S.; Kim, H.; Johns, H. Summary of the evidence on modifiable risk factors for cognitive decline and dementia: A population-based perspective. Alzheimers Dement. 2015, 11, 718-726. [CrossRef]

9. Fonken, L.K.; Frank, M.G.; Gaudet, A.D.; Maier, S.F. Stress and aging act through common mechanisms to elicit neuroinflammatory priming. Brain. Behav. Immun. 2018, 73, 133-148. [CrossRef]

10. Khachaturian, Z.S. Diagnosis of Alzheimer's disease. Arch. Neurol. 1985, 42, 1097-1105. [CrossRef]

11. Dhiman, K.; Blennow, K.; Zetterberg, H.; Martins, R.N.; Gupta, V.B. Cerebrospinal fluid biomarkers for understanding multiple aspects of Alzheimer's disease pathogenesis. Cell. Mol. Life Sci. 2019, 76, 1833-1863. [CrossRef] [PubMed]

12. Scheltens, P.; Blennow, K.; Breteler, M.M.B.; De Strooper, B.; Frisoni, G.B.; Salloway, S.; Van der Flier, W.M. Alzheimer's disease. Lancet 2016, 388, 505-517. [CrossRef]

13. Wright, B.L.C.; Lai, J.T.F.; Sinclair, A.J. Cerebrospinal fluid and lumbar puncture: A practical review. J. Neurol. 2012, 259, 1530-1545. [CrossRef] [PubMed]

14. Shaw, L.M.; Vanderstichele, H.; Knapik-Czajka, M.; Clark, C.M.; Aisen, P.S.; Petersen, R.C.; Blennow, K.; Soares, H.; Simon, A.; Lewczuk, P.; et al. Cerebrospinal fluid biomarker signature in Alzheimer's disease neuroimaging initiative subjects. Ann. Neurol. 2009, 65, 403-413. [CrossRef]

15. Blennow, K.; Dubois, B.; Fagan, A.M.; Lewczuk, P.; De Leon, M.J.; Hampel, H. Clinical utility of cerebrospinal fluid biomarkers in the diagnosis of early Alzheimer's disease. Alzheimers Dement. 2015, 11, 58-69. [CrossRef]

16. Hanger, D.P.; Anderton, B.H.; Noble, W. Tau phosphorylation: The therapeutic challenge for neurodegenerative disease. Trends Mol. Med. 2009, 15, 112-119. [CrossRef]

17. Avila, J.; Lucas, J.J.; Pérez, M.; Hernández, F. Role of Tau Protein in Both Physiological and Pathological Conditions. Physiol. Rev. 2004, 84, 361-384. [CrossRef]

18. Xia, D.; Li, C.; Götz, J. Pseudophosphorylation of Tau at distinct epitopes or the presence of the P301L mutation targets the microtubule-associated protein Tau to dendritic spines. Biochim. Biophys. Acta 2015, 1852, 913-924. [CrossRef]

19. LaPointe, N.E.; Morfini, G.; Pigino, G.; Gaisina, I.N.; Kozikowski, A.P.; Binder, L.I.; Brady, S.T. The amino terminus of tau inhibits kinesin-dependent axonal transport: Implications for filament toxicity. J. Neurosci. Res. 2009, 87, 440-451. [CrossRef]

20. Lebouvier, T.; Pasquier, F.; Buée, L. Update on tauopathies. Curr. Opin. Neurol. 2017, 30, 589-598. [CrossRef]

21. Buée, L.; Delacourte, A. Comparative biochemistry of tau in progressive supranuclear palsy, corticobasal degeneration, FTDP-17 and Pick's disease. Brain Pathol. 1999, 9, 681-693. [CrossRef] [PubMed]

22. Alonso, A.C.; Grundke-Iqbal, I.; Iqbal, K. Alzheimer's disease hyperphosphorylated tau sequesters normal tau into tangles of filaments and disassembles microtubules. Nat. Med. 1996, 2, 783-787. [CrossRef] [PubMed]

23. Arendt, T.; Stieler, J.T.; Holzer, M. Tau and tauopathies. Brain Res. Bull. 2016, 126, 238-292. [CrossRef]

24. Baumann, K.; Mandelkow, E.M.; Biernat, J.; Piwnica-Worms, H.; Mandelkow, E. Abnormal Alzheimer-like phosphorylation of tau-protein by cyclin-dependent kinases cdk2 and cdk5. FEBS Lett. 1993, 336, 417-424. [CrossRef]

25. Arendt, T.; Holzer, M.; Stöbe, A.; Gärtner, U.; Lüth, H.J.; Brückner, M.K.; Ueberham, U. Activated mitogenic signaling induces a process of dedifferentiation in Alzheimer's disease that eventually results in cell death. Ann. N. Y. Acad. Sci. 2000, 920, 249-255. [CrossRef]

26. Neddens, J.; Temmel, M.; Flunkert, S.; Kerschbaumer, B.; Hoeller, C.; Loeffler, T.; Niederkofler, V.; Daum, G.; Attems, J.; Hutter-Paier, B. Phosphorylation of different tau sites during progression of Alzheimer's disease. Acta Neuropathol. Commun. 2018, 6, 52. [CrossRef] [PubMed] 
27. Wang, J.-Z.; Grundke-Iqbal, I.; Iqbal, K. Kinases and phosphatases and tau sites involved in Alzheimer neurofibrillary degeneration. Eur. J. Neurosci. 2007, 25, 59-68. [CrossRef]

28. Sontag, E.; Nunbhakdi-Craig, V.; Lee, G.; Bloom, G.S.; Mumby, M.C. Regulation of the phosphorylation state and microtubule-binding activity of Tau by protein phosphatase 2A. Neuron 1996, 17, 1201-1207. [CrossRef]

29. Wang, X.; Blanchard, J.; Kohlbrenner, E.; Clement, N.; Linden, R.M.; Radu, A.; Grundke-Iqbal, I.; Iqbal, K. The carboxy-terminal fragment of inhibitor-2 of protein phosphatase-2A induces Alzheimer disease pathology and cognitive impairment. FASEB J. Off. Publ. Fed. Am. Soc. Exp. Biol. 2010, 24, 4420-4432. [CrossRef]

30. Louis, J.V.; Martens, E.; Borghgraef, P.; Lambrecht, C.; Sents, W.; Longin, S.; Zwaenepoel, K.; Pijnenborg, R.; Landrieu, I.; Lippens, G.; et al. Mice lacking phosphatase PP2A subunit PR61/B'delta (Ppp2r5d) develop spatially restricted tauopathy by deregulation of CDK5 and GSK3beta. Proc. Natl. Acad. Sci. USA 2011, 108, 6957-6962. [CrossRef]

31. Yoshiyama, Y.; Lee, V.M.Y.; Trojanowski, J.Q. Therapeutic strategies for tau mediated neurodegeneration. J. Neurol. Neurosurg. Psychiatry 2013, 84, 784-795. [CrossRef] [PubMed]

32. Barthélemy, N.R.; Li, Y.; Joseph-Mathurin, N.; Gordon, B.A.; Hassenstab, J.; Benzinger, T.L.S.; Buckles, V.; Fagan, A.M.; Perrin, R.J.; Goate, A.M.; et al. A soluble phosphorylated tau signature links tau, amyloid and the evolution of stages of dominantly inherited Alzheimer's disease. Nat. Med. 2020, 26, 398-407. [CrossRef] [PubMed]

33. Janelidze, S.; Mattsson, N.; Palmqvist, S.; Smith, R.; Beach, T.G.; Serrano, G.E.; Chai, X.; Proctor, N.K.; Eichenlaub, U.; Zetterberg, H.; et al. Plasma P-tau181 in Alzheimer's disease: Relationship to other biomarkers, differential diagnosis, neuropathology and longitudinal progression to Alzheimer's dementia. Nat. Med. 2020, 26, 379-386. [CrossRef]

34. Lapresa, R.; Agulla, J.; Sánchez-Morán, I.; Zamarreño, R.; Prieto, E.; Bolaños, J.P.; Almeida, A. Amyloid-§ promotes neurotoxicity by Cdk5-induced p53 stabilization. Neuropharmacology 2019, 146, 19-27. [CrossRef]

35. Wilkaniec, A.; Gąssowska-Dobrowolska, M.; Strawski, M.; Adamczyk, A.; Czapski, G.A. Inhibition of cyclin-dependent kinase 5 affects early neuroinflammatory signalling in murine model of amyloid beta toxicity. J. Neuroinflammation 2018, 15, 1. [CrossRef]

36. Lee, Y.; Lee, B.H.; Yip, W.; Chou, P.; Yip, B.-S. Neurofilament Proteins as Prognostic Biomarkers in Neurological Disorders. Curr. Pharm. Des. 2020, 25, 4560-4569. [CrossRef]

37. Perea, J.R.; Lleó, A.; Alcolea, D.; Fortea, J.; Ávila, J.; Bolós, M. Decreased CX3CL1 levels in the cerebrospinal fluid of patients with Alzheimer's disease. Front. Neurosci. 2018, 12. [CrossRef]

38. Pickett, E.K.; Herrmann, A.G.; McQueen, J.; Abt, K.; Dando, O.; Tulloch, J.; Jain, P.; Dunnett, S.; Sohrabi, S.; Fjeldstad, M.P.; et al. Amyloid Beta and Tau Cooperate to Cause Reversible Behavioral and Transcriptional Deficits in a Model of Alzheimer's Disease. Cell Rep. 2019, 29, 3592-3604.e5. [CrossRef]

39. Shi, Y.; Manis, M.; Long, J.; Wang, K.; Sullivan, P.M.; Remolina Serrano, J.; Hoyle, R.; Holtzman, D.M. Microglia drive APOE-dependent neurodegeneration in a tauopathy mouse model. J. Exp. Med. 2019, 216, 2546-2561. [CrossRef]

40. Pillai, J.A.; Bena, J.; Bebek, G.; Bekris, L.M.; Bonner-Jackson, A.; Kou, L.; Pai, A.; Sørensen, L.; Neilsen, M.; Rao, S.M.; et al. Inflammatory pathway analytes predicting rapid cognitive decline in MCI stage of Alzheimer's disease. Ann. Clin. Transl. Neurol. 2020. [CrossRef]

41. Podlesniy, P.; Figueiro-Silva, J.; Llado, A.; Antonell, A.; Sanchez-Valle, R.; Alcolea, D.; Lleo, A.; Molinuevo, J.L.; Serra, N.; Trullas, R. Low cerebrospinal fluid concentration of mitochondrial DNA in preclinical Alzheimer disease. Ann. Neurol. 2013, 74, 655-668. [CrossRef] [PubMed]

42. Podlesniy, P.; Llorens, F.; Golanska, E.; Sikorska, B.; Liberski, P.; Zerr, I.; Trullas, R. Mitochondrial DNA differentiates Alzheimer's disease from Creutzfeldt-Jakob disease. Alzheimers. Dement. 2016, 12, 546-555. [CrossRef] [PubMed]

43. Ma, Y.; Jun, G.R.; Chung, J.; Zhang, X.; Kunkle, B.W.; Naj, A.C.; White, C.C.; Bennett, D.A.; De Jager, P.L.; Mayeux, R.; et al. CpG-related SNPs in the MS4A region have a dose-dependent effect on risk of late-onset Alzheimer disease. Aging Cell 2019, 18, e12964. [CrossRef] [PubMed]

44. Kenny, A.; McArdle, H.; Calero, M.; Rabano, A.; Madden, S.F.; Adamson, K.; Forster, R.; Spain, E.; Prehn, J.H.M.; Henshall, D.C.; et al. Elevated Plasma microRNA-206 Levels Predict Cognitive Decline and Progression to Dementia from Mild Cognitive Impairment. Biomolecules 2019, 9, 734. [CrossRef] [PubMed]

45. Li, X.-W.; Li, X.-X.; Liu, Q.-S.; Cheng, Y. Blood and Cerebrospinal Fluid Autoantibody to A $\beta$ Levels in Patients with Alzheimer's Disease: A Meta-Analysis Study. J. Mol. Neurosci. 2020. [CrossRef] 
46. Thijssen, E.H.; La Joie, R.; Wolf, A.; Strom, A.; Wang, P.; Iaccarino, L.; Bourakova, V.; Cobigo, Y.; Heuer, H.; Spina, S.; et al. Diagnostic value of plasma phosphorylated tau181 in Alzheimer's disease and frontotemporal lobar degeneration. Nat. Med. 2020, 26, 387-397. [CrossRef]

47. Barthélemy, N.R.; Horie, K.; Sato, C.; Bateman, R.J. Blood plasma phosphorylated-tau isoforms track CNS change in Alzheimer's disease. J. Exp. Med. 2020, 217. [CrossRef]

48. Palmqvist, S.; Janelidze, S.; Quiroz, Y.T.; Zetterberg, H.; Lopera, F.; Stomrud, E.; Su, Y.; Chen, Y.; Serrano, G.E.; Leuzy, A.; et al. Discriminative Accuracy of Plasma Phospho-tau217 for Alzheimer Disease vs Other Neurodegenerative Disorders. JAMA 2020. [CrossRef]

49. Kenny, A.; Jiménez-Mateos, E.M.; Zea-Sevilla, M.A.; Rábano, A.; Gili-Manzanaro, P.; Prehn, J.H.M.; Henshall, D.C.; Ávila, J.; Engel, T.; Hernández, F. Proteins and microRNAs are differentially expressed in tear fluid from patients with Alzheimer's disease. Sci. Rep. 2019, 9. [CrossRef]

50. Yamin, G.; Teplow, D.B. Pittsburgh Compound-B (PiB) binds amyloid $\beta$-protein protofibrils. J. Neurochem. 2017, 140, 210-215. [CrossRef]

51. Wu, C.; Bowers, M.T.; Shea, J.-E. On the origin of the stronger binding of PIB over thioflavin T to protofibrils of the Alzheimer amyloid- $\beta$ peptide: A molecular dynamics study. Biophys. J. 2011, 100, 1316-1324. [CrossRef] [PubMed]

52. Leuzy, A.; Chiotis, K.; Lemoine, L.; Gillberg, P.-G.; Almkvist, O.; Rodriguez-Vieitez, E.; Nordberg, A. Tau PET imaging in neurodegenerative tauopathies-still a challenge. Mol. Psychiatry 2019, 24, 1112-1134. [CrossRef] [PubMed]

53. Nordberg, A. Amyloid imaging in Alzheimer's disease. Neuropsychologia 2008, 46, 1636-1641. [CrossRef] [PubMed]

54. Johnson, K.A.; Minoshima, S.; Bohnen, N.I.; Donohoe, K.J.; Foster, N.L.; Herscovitch, P.; Karlawish, J.H.; Rowe, C.C.; Carrillo, M.C.; Hartley, D.M.; et al. Appropriate use criteria for amyloid PET: A report of the Amyloid Imaging Task Force, the Society of Nuclear Medicine and Molecular Imaging, and the Alzheimer's Association. Alzheimers Dement. 2013, 9, 1-16. [CrossRef]

55. Cohen, A.D.; Landau, S.M.; Snitz, B.E.; Klunk, W.E.; Blennow, K.; Zetterberg, H. Fluid and PET biomarkers for amyloid pathology in Alzheimer's disease. Mol. Cell. Neurosci. 2019, 97, 3-17. [CrossRef]

56. Hellwig, S.; Domschke, K.; Meyer, P.T. Update on PET in neurodegenerative and neuroinflammatory disorders manifesting on a behavioural level: Imaging for differential diagnosis. Curr. Opin. Neurol. 2019, 32, 548-556. [CrossRef] [PubMed]

57. Shimokawa, N.; Akamatsu, G.; Kadosaki, M.; Sasaki, M. Feasibility study of a PET-only amyloid quantification method: A comparison with visual interpretation. Ann. Nucl. Med. 2020, 34, 629-635. [CrossRef]

58. Hameed, S.; Fuh, J.-L.; Senanarong, V.; Ebenezer, E.G.M.; Looi, I.; Dominguez, J.C.; Park, K.W.; Karanam, A.K.; Simon, O. Role of Fluid Biomarkers and PET Imaging in Early Diagnosis and its Clinical Implication in the Management of Alzheimer's Disease. J. Alzheimers Dis. Rep. 2020, 4, 21-37. [CrossRef]

59. Sacher, C.; Blume, T.; Beyer, L.; Biechele, G.; Sauerbeck, J.; Eckenweber, F.; Deussing, M.; Focke, C.; Parhizkar, S.; Lindner, S.; et al. Asymmetry of fibrillar plaque burden in amyloid mouse models. J. Nucl. Med. 2020. [CrossRef]

60. La Joie, R.; Visani, A.V.; Baker, S.L.; Brown, J.A.; Bourakova, V.; Cha, J.; Chaudhary, K.; Edwards, L.; Iaccarino, L.; Janabi, M.; et al. Prospective longitudinal atrophy in Alzheimer's disease correlates with the intensity and topography of baseline tau-PET. Sci. Transl. Med. 2020, 12, eaau5732. [CrossRef]

61. Hardy, J.; Selkoe, D.J. The amyloid hypothesis of Alzheimer's disease: Progress and problems on the road to therapeutics. Science 2002, 297, 353-356. [CrossRef] [PubMed]

62. Lazarevic, V.; Fieńko, S.; Andres-Alonso, M.; Anni, D.; Ivanova, D.; Montenegro-Venegas, C.; Gundelfinger, E.D.; Cousin, M.A.; Fejtova, A. Physiological Concentrations of Amyloid Beta Regulate Recycling of Synaptic Vesicles via Alpha7 Acetylcholine Receptor and CDK5/Calcineurin Signaling. Front. Mol. Neurosci. 2017, 10, 221. [CrossRef] [PubMed]

63. Wen, Y.; Planel, E.; Herman, M.; Figueroa, H.Y.; Wang, L.; Liu, L.; Lau, L.-F.; Yu, W.H.; Duff, K.E. Interplay between cyclin-dependent kinase 5 and glycogen synthase kinase 3 beta mediated by neuregulin signaling leads to differential effects on tau phosphorylation and amyloid precursor protein processing. J. Neurosci. 2008, 28, 2624-2632. [CrossRef]

64. Xie, L.; Helmerhorst, E.; Taddei, K.; Plewright, B.; Van Bronswijk, W.; Martins, R. Alzheimer's beta-amyloid peptides compete for insulin binding to the insulin receptor. J. Neurosci. 2002, 22, RC221. [CrossRef] [PubMed] 
65. Tokutake, T.; Kasuga, K.; Yajima, R.; Sekine, Y.; Tezuka, T.; Nishizawa, M.; Ikeuchi, T. Hyperphosphorylation of Tau induced by naturally secreted amyloid- $\beta$ at nanomolar concentrations is modulated by insulin-dependent Akt-GSK3 $\beta$ signaling pathway. J. Biol. Chem. 2012, 287, 35222-35233. [CrossRef]

66. Zhang, F.; Gannon, M.; Chen, Y.; Yan, S.; Zhang, S.; Feng, W.; Tao, J.; Sha, B.; Liu, Z.; Saito, T.; et al. $\beta$-amyloid redirects norepinephrine signaling to activate the pathogenic GSK3 $\beta /$ tau cascade. Sci. Transl. Med. 2020, 12, eaay6931. [CrossRef]

67. Babiloni, C.; Blinowska, K.; Bonanni, L.; Cichocki, A.; De Haan, W.; Del Percio, C.; Dubois, B.; Escudero, J.; Fernández, A.; Frisoni, G.; et al. What electrophysiology tells us about Alzheimer's disease: A window into the synchronization and connectivity of brain neurons. Neurobiol. Aging 2020, 85, 58-73. [CrossRef]

68. Horvath, A.; Szucs, A.; Csukly, G.; Sakovics, A.; Stefanics, G.; Kamondi, A. EEG and ERP biomarkers of Alzheimer's disease: A critical review. Front. Biosci. 2018, 23, 183-220. [CrossRef]

69. Adaikkan, C.; Tsai, L.-H. Gamma Entrainment: Impact on Neurocircuits, Glia, and Therapeutic Opportunities. Trends Neurosci. 2020, 43, 24-41. [CrossRef]

70. Kvavilashvili, L.; Niedźwieńska, A.; Gilbert, S.J.; Markostamou, I. Deficits in Spontaneous Cognition as an Early Marker of Alzheimer's Disease. Trends Cogn. Sci. 2020, 24, 285-301. [CrossRef]

71. López-Sanz, D.; Serrano, N.; Maestú, F. The Role of Magnetoencephalography in the Early Stages of Alzheimer's Disease. Front. Neurosci. 2018, 12, 572. [CrossRef] [PubMed]

72. Hampel, H.; Vergallo, A.; Perry, G.; Lista, S. The Alzheimer Precision Medicine Initiative. J. Alzheimers. Dis. 2019, 68, 1-24. [CrossRef] [PubMed]

73. Congdon, E.E.; Sigurdsson, E.M. Tau-targeting therapies for Alzheimer disease. Nat. Rev. Neurol. 2018, 14, 399-415. [CrossRef]

74. Santa-María, I.; Pérez, M.; Hernández, F.; Avila, J.; Moreno, F.J. Characteristics of the binding of thioflavin S to tau paired helical filaments. J. Alzheimers Dis. 2006, 9. [CrossRef] [PubMed]

(C) 2020 by the authors. Licensee MDPI, Basel, Switzerland. This article is an open access article distributed under the terms and conditions of the Creative Commons Attribution (CC BY) license (http://creativecommons.org/licenses/by/4.0/). 